\title{
High frequency jet ventilation is associated with increased levels of plasma $\alpha$-atrial natriuretic peptide - a preliminary study
}

\author{
[La ventilation en jet à haute fréquence est associée à une augmentation des niveaux \\ plasmatiques de peptides natriurétiques auriculaires $\alpha$ - une étude préliminaire]
}

Atsuko Nagatani MD, ${ }^{*}$ Sadayo Niiya MD, $†$ Koji Sumikawa MD $\ddagger$

Purpose: To determine if high frequency jet ventilation (HFJV) influences the secretion of $\alpha$-atrial natriuretic peptide ( $\alpha$ - ANP).

Methods: Sixteen patients undergoing otolaryngeal surgery were studied. Nine patients were subjected to intermittent positive pressure ventilation (IPPV), and seven patients underwent HFJV. Blood samples were drawn for the measurement of plasma $\alpha$-ANP levels and blood gases before anesthesia, and at 30-min after starting either type of ventilation. The study was started at 2:00 p.m., and was completed before surgery. The plasma concentration of $\alpha$-ANP was assayed by radioimmunoassay.

Results: There were no significant differences in mean arterial pressure, heart rate, oxygenation index and $\mathrm{PaCO}_{2}$ between the two groups. IPPV was not associated with any changes in plasma ANP levels, whereas HFJV was associated with significantly increased plasma $\alpha$-ANP levels (from $60.0 \pm 5.7 \mathrm{pg} \cdot \mathrm{mL}^{-1}$ before anesthesia to I I $2.0 \pm 11.6 \mathrm{pg} \cdot \mathrm{mL}^{-1}$ after ventilation, $\mathrm{P}<0.0 \mathrm{I}$ ). The urine output of the HFJV patients was significantly greater than that of the IPPV patients $(P<0.05)$.

Conclusion: These preliminary results suggest that HFJV is associated with a significant increase in plasma ANP and in urine output in anesthetized patients.

Objectif : Déterminer si la ventilation en jet à haute fréquence (VJHF) influence la sécrétion de peptides natriurétiques auriculaires- $\alpha$ (PNA- $\alpha$ ).

Méthode : L'étude a été réalisée auprès de 16 patients devant subir une intervention oto-laryngologique. Neuf patients ont été soumis à une ventilation à pression positive intermittente (VPPI) et sept patients à une VJHF. Des échantillons sanguins ont été prélevés dans le but de mesurer les PNA- $\alpha$ plasmatiques et les gaz sanguins avant l'anesthésie et 30 min après le début de chacun des types de ventila- tion. L'étude a débuté à 14 h et s'est terminée avant l'opération. La concentration plasmatique de PNA- $\alpha$ a été déterminée par un dosage radio-immunologique.

Résultats : Aucune différence intergroupe significative n'a été relevée quant à la tension artérielle moyenne, la fréquence cardiaque, l'index d'oxygénation et la $\mathrm{PaCO}_{2}$. La VPPI n'a été associée à aucun changement plasmatique de PNA- $\alpha$, tandis que la VJHF s'est accompagnée d'une augmentation significative des niveaux plasmatiques de PNA- $\alpha$

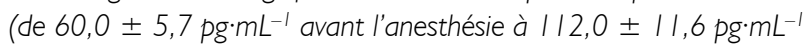
après la ventilation, $P<0,01$ ). Le débit urinaire a été significativement plus élevé avec la VJHF qu'avec la VPPI $(P<0,05)$.

Conclusion : Ces résultats préliminaires permettent d'affirmer que la VJHF est associée à une hausse significative de PNA plasmatiques et du débit urinaire chez les patients anesthésiés.

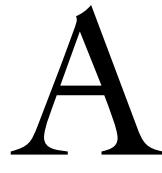

TRIAL natriuretic peptide (ANP) is a cardiac hormone that has potent diuretic, natriuretic and vasorelaxant activities, and plays a role in regulating blood pressure and fluid homeostasis. ${ }^{1}$ Recent studies have suggested that a decrease in the plasma ANP concentration contributes to the renal effects of controlled mechanical ventilation (CMV) with positive end-expiratory pressure (PEEP). ${ }^{2-4}$ On the other hand, the authors have observed that polyuria has often been observed during high frequency jet ventilation (HFJV). However, little is known about the effects of HFJV on the plasma concentration of ANP and renal function. This study was designed to investigate the changes in the plasma ANP concentration during HFJV in comparison to IPPV in a clinical setting.

From the Departments of Anesthesiology, National Nagasaki Medical Center, ${ }^{*}$ Isahaya-Sogo Hospital, $†$ and the Nagasaki University School of Medicine, $\ddagger$ Nagasaki, Japan.

Address correspondence to: Dr. Atsuko Nagatani, Department of Anesthesiology, National Nagasaki Medical Center, Kubara 2-1001-1

Oomura city, Nagasaki 856-8562, Japan. Phone: +81-957-52-3121; Fax: +81-957-54-0292; E-mail tulipcat@nifty.com

Accepted for publication December 3, 2001.

Revision accepted January 18, 2002. 


\section{Methods}

After Institutional approval and informed consent, 16 ASA physical status I or II patients undergoing otolaryngeal surgery were included in this observational, non-randomized study. Nine patients undergoing a tonsillectomy were subjected to intermittent positive pressure ventilation (IPPV). Seven patients undergoing microlaryngosurgery were subjected to HFJV. The experiment was started at 2:00 p.m., and was completed before surgery. All patients were premedicated with atropine sulfate $(0.5 \mathrm{mg})$ and hydroxyzine (1 $\mathrm{mg} \cdot \mathrm{kg}^{-1}, \mathrm{im}$ ) one hour before the induction of anesthesia. A radial artery catheter was inserted under local anesthesia before the induction of anesthesia for blood pressure monitoring and blood sampling.

In both groups, anesthesia was induced with thiamylal $\left(5 \mathrm{mg} \cdot \mathrm{kg}^{-1}\right)$ and succinylcholine chloride $\left(1 \mathrm{mg} \cdot \mathrm{kg}^{-1}\right)$ and was maintained with $60 \%$ nitrous oxide in oxygen. Additional doses of fentanyl, vecuronium, and thiamylal were given as needed. Lactated Ringer's solution was infused at a rate of 3 $\mathrm{mL} \cdot \mathrm{kg}^{-1} \cdot \mathrm{hr}^{-1}$ from 9:00 a.m. to 2:00 p.m., and 7 $\mathrm{mL} \cdot \mathrm{kg}^{-1} \cdot \mathrm{hr}^{-1}$ from 2:00 p.m. until the experiment was completed. The patients all had a Foley catheter inserted immediately after anesthesia was induced and urine output was measured during the protocol.

The trachea of the patients undergoing IPPV was intubated with a RAE (Mallinckrodt ${ }^{\circledR}$, Athlone, Ireland) or a reinforced endotracheal tube (Mallinckrodt ${ }^{\circledR}$, Athlone, Ireland). IPPV was performed at a rate of 10 breaths. $\mathrm{min}^{-1}$ with a tidal volume of $10 \mathrm{~mL} \cdot \mathrm{kg}^{-1}$ (IPPV Group). The trachea of the patients undergoing HFJV was intubated with an Ooita-Taniguchi jet ventilation tube with an internal diameter of $3.0 \mathrm{~mm}$ (Hakko®, Tokyo, Japan). HFJV was performed at a frequency of $3 \mathrm{~Hz}$ with a driving pressure of $1.5 \mathrm{~kg} \cdot \mathrm{cm}^{-2}$ and inspiratory/expiratory time ratio of $1: 1$. The HFJV ventilator (MERA ${ }^{\circledR}, \mathrm{HFO}$ Jet Ventilator AE20, Tokyo, Japan) was equipped with a nitrous oxide oxygen blender (Bird 3M, USA) to maintain a preset nitrous oxide in oxygen mixture.

Blood samples were drawn for the measurement of the plasma $\alpha$-ANP levels and blood gas analysis before anesthesia, and $30 \mathrm{~min}$ after starting either type of ventilation. The blood samples for the $\alpha$-ANP assay were collected in ice-chilled tubes containing EDTA, and were immediately centrifuged and the plasma was frozen until analysis.

The plasma concentration of $\alpha$-ANP was assayed by a radioimmunoassay (RIA) kit (Eiken ICL, Tokyo, Japan) as follows. ${ }^{5}$ Standards or samples were mixed with the anti-ANP serum and incubated for $24 \mathrm{hr}$ at $4^{\circ} \mathrm{C} .\left[{ }^{125} \mathrm{I}\right] \alpha$ - ANP was added, and was followed by a
TABLE I Patient profile and fluid intake

\begin{tabular}{lllllll}
\hline & \multicolumn{3}{c}{$\operatorname{IPPV}(n=9)$} & \multicolumn{3}{c}{ HFJV $(n=7)$} \\
& Mean & SE & Range & Mean & SE & Range \\
\hline Age $(\mathrm{yr})$ & 28.4 & 5.6 & $16-65$ & $40.4^{*}$ & 6.0 & $24-68$ \\
Height $(\mathrm{cm})$ & 159.7 & 3.2 & $144-177$ & 163.9 & 2.9 & $154-176$ \\
Weight $(\mathrm{kg})$ & 55.2 & 2.7 & $46-66$ & 59.2 & 2.8 & $44-67$ \\
Fluid volume & 3.80 & 0.2 & $2.8-4.6$ & 3.46 & 0.26 & $2.8-4.6$ \\
$\left(\mathrm{~mL} \cdot \mathrm{kg}^{-1} \cdot 30 \mathrm{~min}^{-1}\right)$ & & & & & \\
\hline
\end{tabular}

$\mathrm{IPPV}=$ intermittent positive pressure ventilation; $\mathrm{HFJV}=$ high frequency jet ventilation. ${ }^{*} \mathrm{P}=0.0502$ by Mann- Whitney $\mathrm{U}$ test.

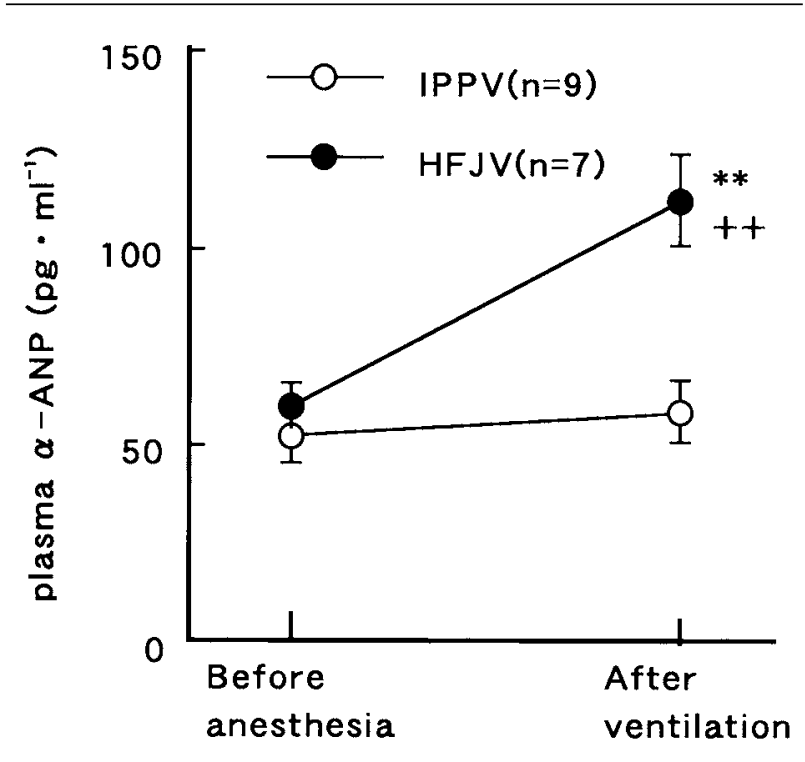

FIGURE 1 Plasma $\alpha$-atrial natriuretic peptide (ANP) concentrations $\left(\mathrm{pg} \cdot \mathrm{mL}^{-1}\right)$ in patients undergoing high frequency jet ventilation (HFJV) and intermittent positive pressure ventilation (IPPV) before anesthesia and $30 \mathrm{~min}$ after starting ventilation. ${ }^{* *} \mathrm{P}<0.01$ vs before anesthesia; ††P $<0.01$ vs IPPV.

further incubation for $24 \mathrm{hr}$ at $4^{\circ} \mathrm{C}$. The bound and free fractions of $\alpha$-ANP were separated by double antibody precipitation. The radioactivity in the precipitate centrifuged for $30 \mathrm{~min}$ at $3,000 \mathrm{rpm}$ was then measured. The amount of $\alpha$-ANP in the sample was determined from a standard curve drawn using the values obtained from the assay of the $\alpha$-ANP standard.

The basal plasma concentration of $\alpha$-ANP in healthy adults is $8.3 \sim 61.1 \mathrm{pg} \cdot \mathrm{mL}^{-1}$.

All values are expressed as means \pm SE. The statistical analysis was performed using the Mann-Whitney $\mathrm{U}$ test or two-way analyses of variance (ANOVAs) with Scheffe's post-hoc test. $P$ values less than 0.05 were considered to be statistically significant. 


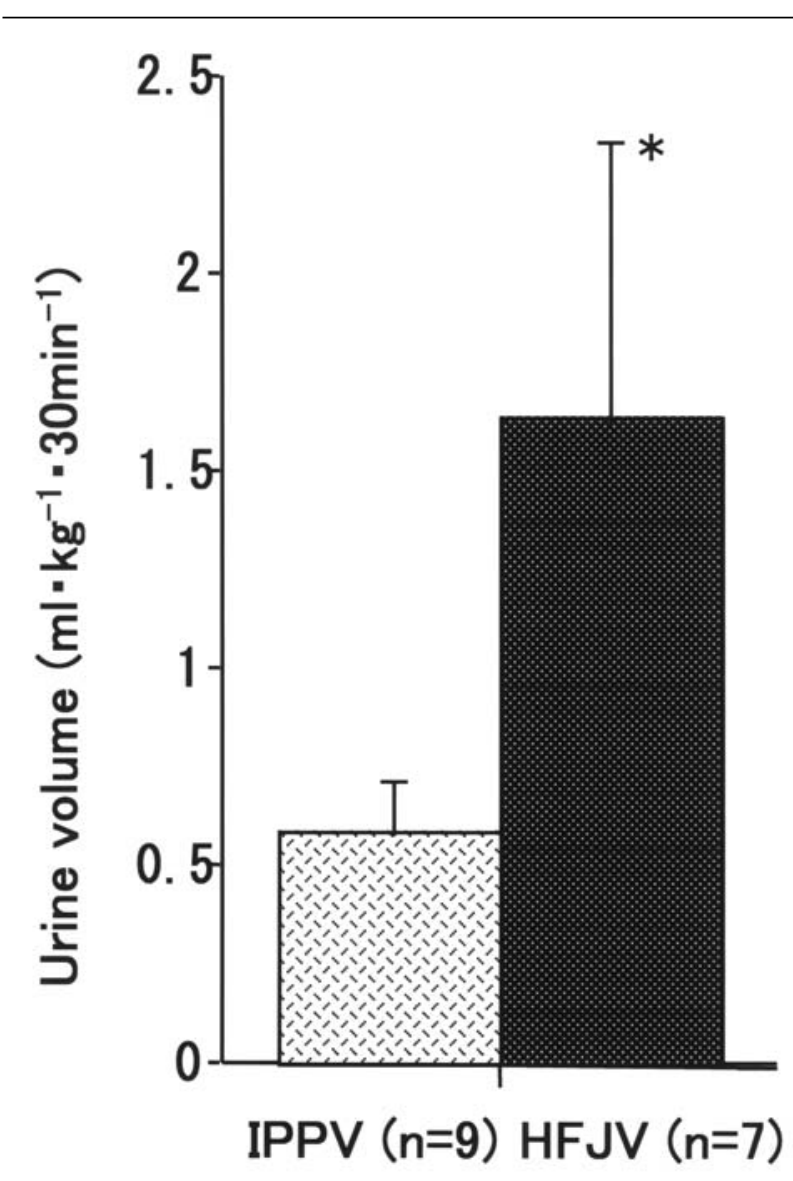

FIGURE 2 Urine volume in patients undergoing high frequency jet ventilation (HFJV) and intermittent positive pressure ventilation (IPPV). ${ }^{*} \mathrm{P}<0.05$ ps IPPV.

\section{Results}

There were no significant differences in age, body weight, height or fluid volume except for the gender ratio between the two groups (Table I).

The plasma $\alpha$-ANP concentration in the IPPV Group showed no change after ventilation $(58.8 \pm 7.8$ $\left.\mathrm{pg} \cdot \mathrm{mL}^{-1}\right)$ as compared to the pre-anesthesia level $\left(52.5 \pm 5.1 \mathrm{pg} \cdot \mathrm{mL}^{-1}\right)$. In the HFJV Group, the $\alpha$-ANP concentration increased significantly from $60.0 \pm 5.7 \mathrm{pg} \cdot \mathrm{mL}^{-1}$ before anesthesia to $112.0 \pm 11.6$ $\mathrm{pg} \cdot \mathrm{mL}^{-1}$ after ventilation $(\mathrm{P}<0.01$; Figure 1$)$.

Figure 2 shows urine output in the HFJV and IPPV groups. The mean urine output in the HFJV patients was significantly greater than in the IPPV patients $(\mathrm{P}<0.05)$. There were no significant differences in the mean arterial pressure, heart rate, oxygenation index (the ratio of $\mathrm{PaO}_{2}$ to $\mathrm{FIO}_{2}$ ) or the $\mathrm{PaCO}_{2}$ between the two groups (Table II). The oxygenation index was well maintained during ventilation in both groups. The $\mathrm{PaCO}_{2}$ did not change during ventilation in either group.

\section{Discussion}

The results from the present study show that HFJV is associated with a significant increase in the plasma level of $\alpha$-ANP, whereas IPPV is associated with stable plasma $\alpha$-ANP levels. Also, the urine output in the HFJV patients was greater than in the IPPV patients. Respiratory management with HFJV provided adequate gas exchange with hemodynamic stability equivalent to IPPV. These findings suggest that HFJV may stimulate the release of $\alpha$-ANP from the atrial myocytes, thus resulting in an increase in urine volume.

Alpha-ANP, an active circulatory peptide that has potent diuretic, natriuretic, and vasorelaxant activities in healthy humans, is mainly released from membranebound granules in the atrial myocardial cells. ${ }^{6}$ Zimmerman et al. reported that when $\alpha$-ANP was infused exogenously at the lowest infusion rate in anesthetized dogs, the circulating $\alpha$-ANP levels (increased to $31 \pm 3 \mathrm{pg} \cdot \mathrm{mL}^{-1}$ ) resulted in an increase of urine flow with no change in hemodynamic state. ${ }^{7}$ Thus, it is possible that the increased plasma $\alpha$-ANP levels exerted a diuretic action without any hemodynamic change in the present study.

Controlled mechanical ventilation with PEEP is often used to correct the hypoxemia of acute respiratory failure, but induces antidiuresis and fluid retention. Many experimental and clinical studies have demonstrated that the decrease in urine output induced by PEEP is mediated in part by a decrease in the secretion of $\alpha$-ANP, secondary to a reduction in the atrial transmural pressure. ${ }^{2}$ In contrast, as shown in the present study, HFJV increased the plasma $\alpha$-ANP concentration and the urine output.

Although the mechanisms responsible for the elevated plasma $\alpha$-ANP levels during HFJV patients are not clear, the following three explanations may be proposed. First, the vibration due to HFJV might evoke the atrial release of $\alpha$-ANP. It has been suggested that changes in the atrial rhythm and pressure may modulate the release of $\alpha$-ANP from the atrium, and that this mechanism might contribute to the polyuria associated with atrial fibrillation and paroxysmal supraventricular tachyarrhythmia. ${ }^{8}$ Furthermore, Obata et al. examined $\alpha$-ANP secretion in response to cardiac pacing at a rate of up to 150 beats. $\mathrm{min}^{-1}$ for ten minutes, ${ }^{9}$ and suggested that the electrical stimulation itself might be a potent stimulus for $\alpha$-ANP secretion. Although HFJV does not stimulate the atrium electrically, rapid vibrations secondary to HFJV could be responsible for increased 
TABLE II Hemodynamic and blood gas values

\begin{tabular}{lllll}
\hline & Control & IPPV $(n=9)$ & HFJV $(n=7)$ & $\begin{array}{l}\text { After } \\
\text { ventilation }\end{array}$ \\
& & $\begin{array}{l}\text { After } \\
\text { ventilation }\end{array}$ & $78.0 \pm 5.1$ & $81.4 \pm 6.8$ \\
$\mathrm{HR}\left(\right.$ beats. $\left.\mathrm{min}^{-1}\right)$ & $82.2 \pm 5.4$ & $96.1 \pm 3.7$ & $101.9 \pm 5.5$ & $108.0 \pm 5.0$ \\
$\mathrm{MAP}(\mathrm{mmHg})$ & $90.8 \pm 4.0$ & $570.5 \pm 18.9$ & $440.9 \pm 22.8$ & $423.9 \pm 56.8$ \\
$\begin{array}{l}\text { Oxygenation } \\
\text { index }\end{array}$ & $481.5 \pm 24.7$ & $33.9 \pm 2.8$ & $37.4 \pm 1.7$ & $33.9 \pm 4.1$ \\
$\mathrm{PaCO}_{2}(\mathrm{mmHg})$ & $39.7 \pm 2.5$ & 3.1 & \\
\hline
\end{tabular}

Values are mean $\pm \mathrm{SE}$; IPPV $=$ intermittent positive pressure ventilation; HFJV = high frequency jet ventilation; $\mathrm{HR}=$ heart rate; MAP $=$ mean arterial blood pressure; Oxygenation index $=\mathrm{PaO}_{2} / \mathrm{FIO}_{2}$.

$\alpha$-ANP secretion. Second, HFJV may release the atrial compression caused by the lung and increase venous return, thus resulting in a stretch of the atrial tissues and an increase in -ANP secretion. Atrial stretch acts as the principal mediator controlling the acute release of ANP, ${ }^{10}$ and elevated plasma levels of $\alpha$-ANP have been found in volume-expanded healthy volunteers. ${ }^{3,4}$ However, this mechanism is unlikely, because HFJV cannot decrease the intrathoracic pressure as compared to spontaneous breathing. Thus, there would be no increase in either venous return or in atrial transmural pressure. Third, the reduced metabolic clearance of $\alpha$ ANP during HFJV may result in the increased plasma $\alpha$-ANP levels. The glomerular filtration rate and the effective renal plasma flow correlate with the renal clearance of ANP, in which the clearance receptor for ANP (ANP-C) plays an essential role. ${ }^{11}$ ANP-C downregulation may also be involved in the reduction in the metabolic clearance of $\alpha$-ANP in preeclampsia. ${ }^{12}$ However, this mechanism is unlikely, because the renal function, volemic status, and blood pressure were all normal in all patients in the present study.

A limitation of our study is that patients were not divided into two groups in a randomized fashion. However, all other conditions that might affect the physiological stimuli for $\alpha$-ANP, except for ventilation, were identical between groups. The gender ratio differed between groups, but plasma $\alpha$-ANP levels are similar males and females. ${ }^{13}$ Finally, it seems unlikely that the different diseases themselves would have influenced the results. Further study is required to determine the exact mechanisms involved in the increased plasma $\alpha$-ANP levels during HFJV, including its time course and a measurement of atrial transmural pressure.

Bauer et al. investigated the plasma ANP concentration in preterm infants, and reported that there was no difference in the ANP concentrations between the ventilatory modes of high-frequency oscillatory ventilation (HFOV) and IPPV. ${ }^{14}$ Their results appear to be inconsistent with ours. However, Bauer's HFOV
Group had a significantly higher mean airway pressure compared with the IPPV Group, and thus it is possible that the effect of HFOV on ANP secretion might be cancelled by a high airway pressure.

In conclusion, in our preliminary study, HFJV was associated with increases in plasma $\alpha$-ANP levels and urine output, suggesting HFJV might stimulate directly the secretion of $\alpha$-ANP by a mechanism that remains to be determined.

\section{References}

1 Laragh $\mathrm{JH}$. Atrial natriuretic hormone, the renin-aldosterone axis, and blood pressure-electrolyte homeostasis. N Engl J Med 1985; 313: 1330-40.

2 Shirakami G, Magaribuchi T, Shingu $K$, et al. Positive end-expiratory pressure ventilation decreases plasma atrial and brain natriuretic peptide levels in humans. Anesth Analg 1993; 77: 1116-21.

3 Frass M, Popovic R, Hartter E, Auinger C, Woloszczuk $W$, Leithner $C$. Atrial natriuretic peptide decrease during spontaneous breathing with continuous positive airway pressure in volume-expanded healthy volunteers. Crit Care Med 1988; 16: 831-5.

4 Beuret P, Feibl F, Nussberger J, Brunner H-R, Perret C. Volemic status influences the response of plasma atrial natriuretic factor to positive airway pressure. Chest 1996; 109: 1313-9.

5 Terasaki K, Jibiki K, Odagiri E, Demura R, Demura $H$. Basic and clinical evaluation of human atrial natriuretic polypeptide (hANP) RIA kit. Journal of Tokyo Women's Medical College 1988; 58 1048-55.

6 de Bold AJ. Atrial natriuretic factor: a hormone produced by the heart. Science 1985; 230: 767-70

7 Zimmerman RS, Schirger JA, Edwards BS, Schwab TR, Henblein DM, Bernett JC Jr. Cardio-renal- endocrine dynamics during stepwise infusion of physiologic and pharmacologic concentrations of atrial natriuretic factor in the dog. Circ Res 1987; 60: 63-9.

8 Roy D, Paillard F, Cassidy D, et al. Atrial natriuretic factor during atrial fibrillation and supraventricular 
tachycardia. J Am Coll Cardiol 1987; 9: 509-14.

9 Obata K, Yasue H, Horio $\Upsilon$, et al. Increase of human atrial natriuretic polypeptide in response to cardiac pacing. Am Heart J 1987; 113: 845-7

10 Edwards BS, Zimmerman RS, Schwab TR, Heublein $D M$, Bernett JC Jr. Atrial stretch, not pressure, is the principal determinant controlling the acute release of atrial natriuretic factor. Circ Res 1988; 62: 191-5.

11 Hashimoto $\Upsilon$, Nakao K, Hama $N$, et al. Clearance mechanisms of atrial and brain natriuretic peptides in rats. Pharm Res 1994; 11: 60-4.

12 Irons DW, Baylis PH, Butler TJ, Davison JM. Atrial natriuretic peptide in preeclampsia: metabolic clearance, sodium excretion and renal hemodynamics. Am J Physiol 1997; 273: F483-7.

13 Naruse $M$, Naruse $K$, Obana $K$, et al. Immunoreactive -human atrial natriuretic polypeptide in human plasma. Peptides 1986; 7: 141-5.

14 Bawer K, Buschkamp S, Marcinkowski M, Kossel H, Thome U, Versmold HT. Postnatal changes of extracellular volume, atrial natriuretic factor, and diuresis in a randomized controlled trial of high-frequency oscillatory ventilation versus intermittent positive-pressure ventilation in premature infants $<30$ weeks gestation. Crit Care Med 2000; 28: 2064-8. 